\title{
PENERAPAN PENDEKATAN CONTEXTUAL TEACHING AND LEARNING (CTL) UNTUK MENINGKATKAN HASIL BELAJAR GEOGRAFI SISWA KELAS $X$ IPS MAN 2 KABUPATEN KONAWE SELATAN PADA MATERI POKOK LITOSFER
}

\author{
Andika Dwi Widiyantoro ${ }^{1}$ \\ ${ }^{1}$ Program Studi Pendidikan Geografi, Universitas Halu Oleo, Kendari.
}

\begin{abstract}
The problems examined are: 1) the description of the learning activities of students 2) Description of activity teaching teacher 3) increase in the results of the study. The research aims to 1) Describe student learning activities, 2) Describes the activity of teaching teachers. 3) Determine the increase in the results of the study. This type of research is Research Action class (RAA) which has been implemented 2 cycle. The subject of this research students are registered on the even-numbered year semester lesson 2016/2017 amounted to 23 people. The data source of this research activity is to teach teachers and learning activities of students obtained from the observation sheet and the results of learning as measured through tests. The data type used is the quantitative and qualitative. The results showed that 1) learning activities at each cycle tends to increase. This is demonstrated by average score on each cycle, on cycle I average score activity students are increasing at 2.7 cycle II be 3.2. cycle I 2) on average score 2.7 teacher teaching activity is increased in cycle II be 3.2. Learning Outcome 3) geography enhanced through Contextual learning model of Teaching And Learning (CTL). On cycle I students who complete $12(52.2 \%)$ and not completely and absolutely no $9(33,33 \%)$ with an average of 66 while on the second cycle was increased to $19(83 \%)$ of students who completely and $4(17 \%)$ students do not complete an average of 78.17 .
\end{abstract}

\section{Kata kunci: Learning Model, Process, Result of the Study}

\section{PENDAHULUAN}

Dalam proses pembelajaran dikelas guru memiliki peranan yang sangat penting yaitu bagaimana guru membimbing, melatih, dan membina siswa agar memahami setiap pelajaran yang disampaikan oleh guru. Untuk itu salah satu yang harus diperhatikan seorang guru adalah cara mengajar yaitu membawakan materi pelajaran agar mudah dimaknai oleh siswa. Cara mengajar guru sangat penting, untuk itu dibutuhkan kreatifitas seorang guru dalam mengelola pembelajaran dikelasnya yaitu menciptakan kevariasian dalam mengajar dengan menerapkan model pembelajaran yang memungkinkan siswa mencari tahu dan menemukan sendiri konsep dan prinsip materi yang diajarkan, dengan menghubungkan antara materi yang dipelajari dengan konteks keseharian siswa di lingkunganya dengan begitu pembelajaran yang dilakukan siswa akan lebih bermakna serta siswa dapat memahami konsep dan prinsip materi yang diajarkan dan berdampak pada peningkatan hasil belajar siswa.. Berdasarkan hasil observasi awal dan tanya jawab dengan guru mata pelajaran geografi siswa kelas $X$ IPS MAN 2 Konawe Selatan diperoleh informasi bahwa kualitas hasil belajar pada ulangan harian materi litosfer masih tergolong masih rendah atau belum mencapai standar kriteria ketuntasan minimal yang telah ditetapkan yaitu 70,00. Hal ini 
terlihat dari nilai rata-rata hasil belajar yang diperoleh siswa tahun 2015/2016 pada semester genap yaitu 60,00 dan tingkat ketuntasan siswa $63 \%$. Sebagaimana dari 22 siswa hanya 14 orang yang memperoleh nilai 70 sesuai KKM yang telah ditentukan sekolah. Berdasarkan pemaparan tersebut maka penulis melakukan suatu penelitian tindakan kelas (PTK) dengan judul "Penerapan Pendekatan Contextual Teaching And Learning (CTL) Untuk Meningkatkan Hasil Belajar Geografi Siswa Kelas X IPS MAN 2 Kabupaten Konawe Selatan Pada Materi Pokok Litosfer.

\section{METODE PENELITIAN}

Penelitian ini dilaksanakan pada tanggal 9 - 30 Januari 2017 semester genap tahun ajaran 2016/2017 di MAN 2 Kabupaten Konawe selatan kelas $\mathrm{X}$ IPS. Jenis penelitian ini adalah penelitian tindakan kelas (PTK). Faktor-faktor yang diteliti dalam penelitian tindakan kelas ini adalah: 1) Faktor siswa 2) Faktor guru 3) Faktor hasil belajar. Teknik pengumpulan data yaitu: 1) Teknik Observasi, 2) teknik evaluasi/tes. Instrumen penelitian ini terdiri atas tiga jenis, yaitu: 1) lembar observasi untuk memperoleh data aktivitas guru, 2) lembar observasi aktivitas siswa, 3) instrumen tes. Data yang diperoleh dalam penelitian tindakan kelas ini dianalisis dengan analisis deskriptif.. Indikator kinerja dalam penelitian ini yaitu: 1) segi proses, 2) segi hasil.

\section{HASIL PENELITIAN}

\section{Data Aktivitas Belajar Siswa Siklus I}

Data skor aktivitas belajar siswa dalam kegiatan belajar mengajar pada Siklus I dapat dilihat pada tabel 3.1. berikut:

Tabel 3.1. Data Aktivitas Belajar Siswa Siklus I

\begin{tabular}{lllll}
\hline \multirow{2}{*}{ No } & \multicolumn{1}{c}{$\begin{array}{c}\text { Indikator aktivitas siswa yang } \\
\text { dinilai }\end{array}$} & Pert 1 & Pert 2 & Rata-rata \\
\cline { 5 - 5 } & Kegiatan Awal & 3 & 3 & 3 \\
\hline $\begin{array}{l}\text { Siswa menyimak dengan fokus saat } \\
\text { pemeriksaan kehadiran dan } \\
\text { menyiapkan diri untuk belajar }\end{array}$ & $\begin{array}{l}\text { Skor/Siklus 1 } \\
\text { Siswa memperhatikan berbagai alat } \\
\text { bantu dan sumber belajar yang } \\
\text { berkaitan dengan materi yang akan } \\
\text { dipelajari }\end{array}$ & 2 & 3 & 2,5 \\
\hline 3 & $\begin{array}{l}\text { Siswa mengingat kembali materi } \\
\text { sebelumnya }\end{array}$ & 3 & 4 & 3,5 \\
\hline 4 & Siswa termotivasi untuk belajar & 2 & 3 & 2,5 \\
\hline
\end{tabular}




\begin{tabular}{lllll}
5 & $\begin{array}{l}\text { Siswa mendengarkan dengan } \\
\text { seksama apa yang disampaikan }\end{array}$ & 2 & 3 & 2,5 \\
\hline 6 & $\begin{array}{l}\text { Siswa menyimak penjelasan yang } \\
\text { diterapkan }\end{array}$ & 2 & 3 & 2,5 \\
\hline
\end{tabular}

Kegiatan Inti

\begin{tabular}{|c|c|c|c|c|}
\hline 7 & $\begin{array}{l}\text { Siswa mengemukakan pemahaman } \\
\text { awalnya terhadap materi, } \\
\text { pemahaman awal tersebut,dijadikan } \\
\text { acuan untuk menyelidikinya } \\
\text { (kontruktivisme) }\end{array}$ & 3 & 3 & 3 \\
\hline 8 & $\begin{array}{l}\text { Siswa bekerja sama dalam } \\
\text { kelompok-kelompok kecil (learning } \\
\text { community) }\end{array}$ & 2 & 2 & 2 \\
\hline 9 & $\begin{array}{l}\text { Setiap kelompok siswa } \\
\text { mendiskusikan LKS menemukan } \\
\text { alternative pemecahan masalah } \\
\text { terhadap masalah, dan apa yang akan } \\
\text { dilakukan setelah keputusan itu telah } \\
\text { tercapai, dengan menghubungkan } \\
\text { persoalan tersebut dengan konteks } \\
\text { dilingkungan siswa sendiri (inkuiry) }\end{array}$ & 2 & 3 & 2,5 \\
\hline 10 & $\begin{array}{l}\text { Siswa mengemukakan gambaran dan } \\
\text { contoh cara mengerjakan LKS }\end{array}$ & 3 & 3 & 3 \\
\hline 11 & $\begin{array}{l}\text { Siswa dalam kelompok saling } \\
\text { bertanya untuk bertukar pendapat } \\
\text { untuk memecahkan persoalan yang } \\
\text { diberikankepada mereka dalam } \\
\text { diskusi kelompok }\end{array}$ & 2 & 2 & 2 \\
\hline 12 & $\begin{array}{l}\text { Siswa mencatat hasil diskusi } \\
\text { kelompok mereka, serta mengingat } \\
\text { kembali kejadian-kejadian yang } \\
\text { dianggap kurang penting yang dapat } \\
\text { mengganggu jalanya proses diskusi } \\
\text { dalam kelompok }\end{array}$ & 2 & 3 & 2,5 \\
\hline
\end{tabular}


13 Siswa mempresentasikan hasil diskusi kelompok mereka

3

3

3

\begin{tabular}{lllll}
\hline 14 & $\begin{array}{l}\text { Siswa menanggapi pekerjaan } \\
\text { temanya }\end{array}$ & 2 & 4 & 3 \\
\hline 15 & $\begin{array}{l}\text { Mengumpulkan hasil diskusi } \\
\text { kelompoknya kepada guru dan siswa } \\
\text { menanyakan materi yang kurang } \\
\text { dimengerti }\end{array}$ & 3 & 4 & 3,5 \\
\hline 16 & $\begin{array}{l}\text { Siswa menyimpu l kan materi } \\
\text { pelajaran yang telah dipelajari }\end{array}$ & 3 & 3 & 3 \\
\hline 17 & $\begin{array}{l}\text { Siswa mencatat tugas rumah } \\
\text { Rata-rata aktivitas siswa untuk } \\
\text { semua aspek }\end{array}$ & $\mathbf{2 , 4}$ & $\mathbf{3 , 0}$ & $\mathbf{2 , 7}$ \\
\hline Kategori & 3 & & 2,5 \\
\hline
\end{tabular}

Sumber: Data Diolah (2017)

Gambaran rata-rata aktivitas belajar siswa pada siklus I untuk setiap satuan aktivitas

belajar yang dinilai dapat dilihat pada Gambar 3.1 berikut:

\section{SIKLUS 1}

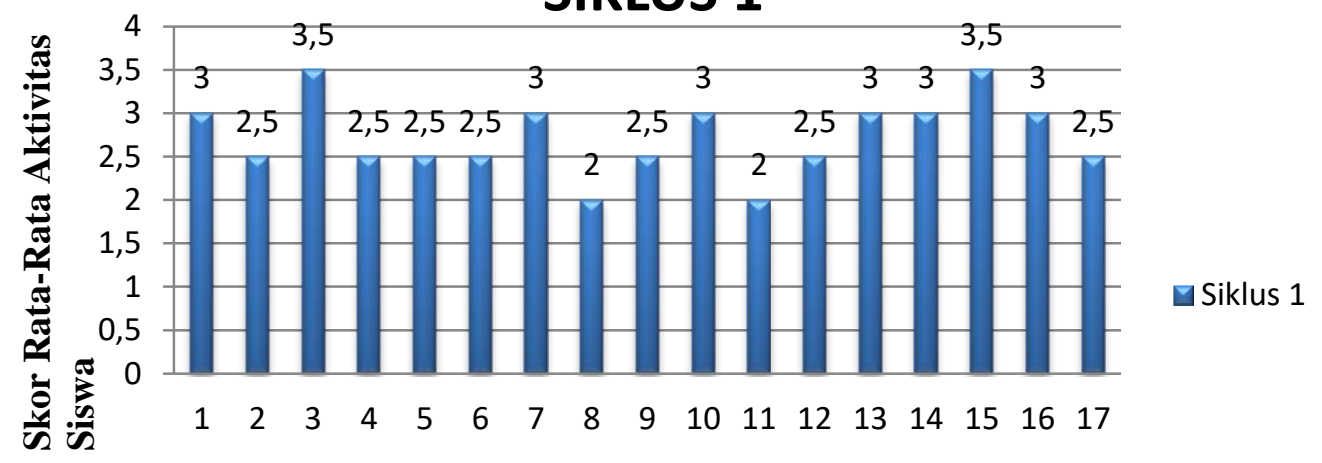

Aktivitas Belajar Siswa

Gambar 3.1 Grafik Skor Rata-rata Satuan Aktivitas Belajar Siswa Siklus I 
Untuk mendapatkan gambaran rata-rata aktivitas belajar siswa selama pembelajaran pada siklus I pada

pertemuan I dan II dapat dilihat pada Gambar 3.2 berikut:

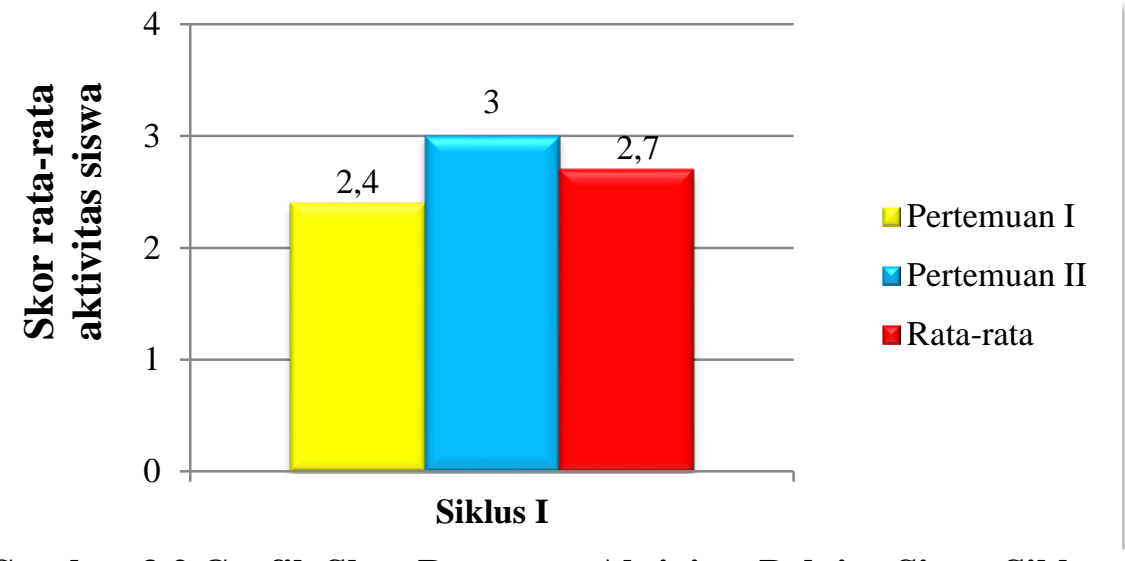

Gambar 3.2 Grafik Skor Rata-rata Aktivitas Belajar Siswa Siklus

\section{Data Aktivitas Guru Siklus I}

Gambaran aktivitas gur pada siklus I dapat dilihat pada tabel 3.2 berikut :

Tabel 3.2 Skor Rata-rata Aktivitas Guru Siklus I

\begin{tabular}{|c|c|c|c|}
\hline \multirow{2}{*}{ No } & \multirow{2}{*}{ Indikator aktivitas guru yang dinilai } & $\begin{array}{c}\text { Skor/Siklus } \\
1 \\
\end{array}$ & \\
\hline & & Pert 1 & Pert 2 \\
\hline
\end{tabular}

\section{Kegiatan Awal}

1. Guru memeriksa kehadiran siswa termasuk mempersiapkan siswa belajar

$3 \quad 3 \quad 3$

2. Guru mempersiapkan berbagai alat bantu dan sumber belajar

3

$3 \quad 3$

3. Guru melakukan apersepsi tentang materi yang akan di pelajari

$2 \quad 3 \quad 2,5$

4. Memotivasi siswa untuk mengikuti pelajaran

2

2

2

5. Menyampaikan tujuan pembelajaran

3

3 
Mengemukakan langkah-langkah apa yang

6. akan dilakukan selama proses pembelajaran

3

3

3 berlangsung

Kegiatan Inti

7. Guru mengemukakan informasi mengenai materi

3

$3 \quad 3$

Guru mendorong siswa mengemukakan pemahaman awalnya terhadap

8. materi,pemahaman awal tersebut dijadikan

2

$3 \quad 2,5$ acuan untuk menyelidikinya (kontruktivisme)

Guru membentuk, dan membimbing siswa

9. bekerja sama dalam kelompok-kelompok kecil (learning community)

Guru memberikan persoalan kepada setiap kelompok siswa,tetapi masih pada materi pelajaran yang sama,dimana setiap kelompok diajak berlatih mendiskusikan

10. LKS,menemukan alternative pemecahan terhadap masalah,dan apa yang akan dilakukan setelah keputusan itu telah tercapai, dengan menghubungkan persoalan tersebut dengan konteks di lingkungan siswa sendiri (inkuiry)

Guru meberikan gambaran gambaran dan

11. contoh cara mengatasi suatu persoalan dalam suato organisasi (pemodelan) 
mendorong,membimbing,dan menilai

kemampuan siswa bekerja secara kelompok

dengan mengajukan pertanyaan-pertanyaan

yang mengacu perkembangan pemahaman

12. mereka terhadap persoalan-persoalan yang

diberikan kepada mereka, dengan

2

menghubungkan antara materi dengan

konteks keseharian siswa dilingkunganya

(questioning)

13. guru membimbing siswa mencatat hasil

diskusi kelompok mereka

4

$4 \quad 4$

2

14. guru membimbing jalanya diskusi

$3 \quad 3$

3

15. mengumpulkan hasil diskusi kelompok siswa

3

3

3

\section{C.kegiatan Akhir}

16. Guru memberikan kesimpuln terhadap materi yang telah dipelajari

2

$2 \quad 2$

Guru membimbing siswa untuk mengingat kembali kejadian-kejadian yang dianggap

17. penting dan kurang penting yang dapat mengganggu proses diskusi dalam kelompok

3

$4 \quad 3,5$ (reflection)

\begin{tabular}{lccc} 
18. Guru memberi tugas kepada siswa & 2 & 3 & 2,5 \\
\hline Rata-rata aktivitas guru & $\mathbf{2 , 6}$ & $\mathbf{2 , 9}$ & $\mathbf{2 , 7}$
\end{tabular}

Kategori

Cukup 
Sumber: Data Diolah (2017)

Gambaran rata-rata aktivitas guru pada siklus I dapat dilihat pada Gambar 3.3 berikut :

\section{Siklus I}

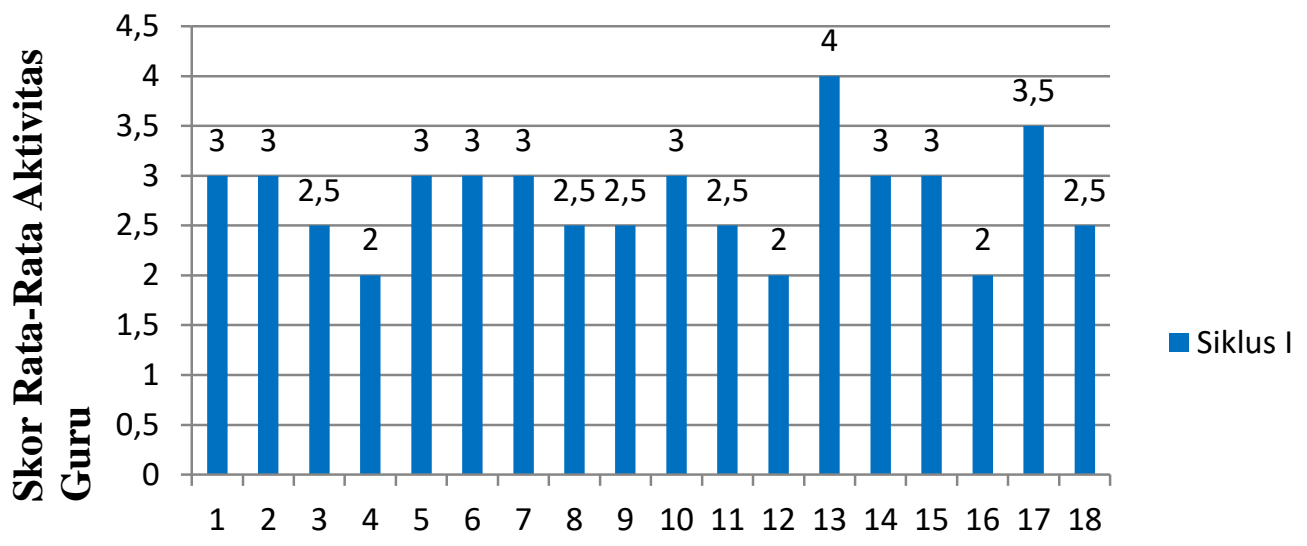

Aktivitas Guru

\section{Gambar 3.3 Grafik Skor Rata-rata Satuan Aktivitas Guru Siklus I}

gambaran rata-rata aktivitas guru pada siklus I pada pertemuan dapat dilihat pada Gambar 3.4 berikut:

Gambar 3.4 Grafik Skor Rata-rata Aktivitas Guru Siklus I

Berdasarkan analisis data hasil belajar siswa pada siklus I diperoleh hasil sebagaimana disajikan pada tabel 3.3 berikut: 
Tabel 3.3 Data Analisis Ketuntasan Hasil Belajar Siswa Siklus I

\begin{tabular}{llcl}
\hline \multicolumn{1}{c}{ Skor } & Jumlah siswa & Presentase & Ketuntasan Belajar \\
\hline $0-69$ & 11 orang & $47,8 \%$ & Belum Tuntas \\
\hline $70-100$ & 12 orang & $52,2 \%$ & Sudah Tuntas \\
\hline Jumlah & $\mathbf{2 3}$ orang & $\mathbf{1 0 0 \%}$ & \\
\hline Keterangan & $:$ & & \\
\hline Tidak Tuntas & $\mathbf{1 1}$ orang & \\
\hline Tuntas & $\mathbf{1 1 2}$ orang & \\
\hline Nilai Rata-rata & $\mathbf{: 6 6}$ & \\
\hline Nilai Maksimum & $\mathbf{: 8 0}$ \\
\hline Nilai Minimum & $\mathbf{0 4 3 , 3}$ & \\
\hline Presentase Ketuntasan: $\mathbf{5 2 , 2} \%$ \\
\hline
\end{tabular}

Sumber: Data Diolah (2017)

Untuk gambaran hasil belajar siswa pada siklus I dapat dilihat pada gambar 3.5 berikut:

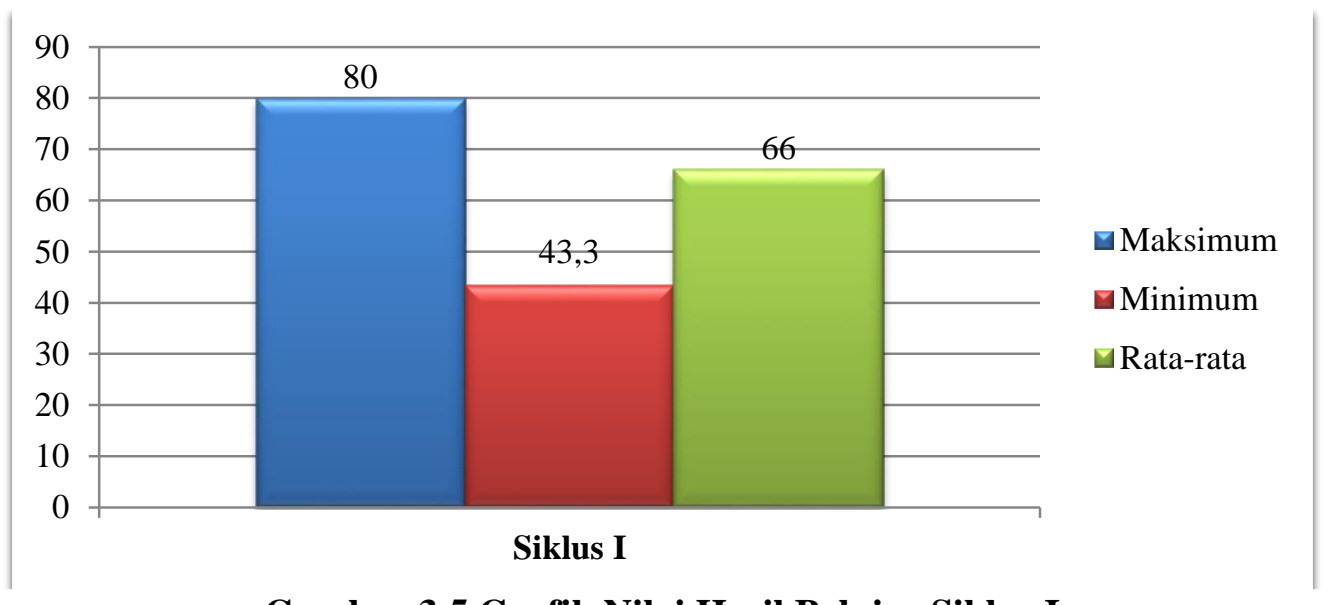

Gambar 3.5 Grafik Nilai Hasil Belajar Siklus I 
analisis ketuntasan belajar siswa pada siklus I diperoleh hasil sebagaimana

disajikan pada gambar 3.6 berikut:

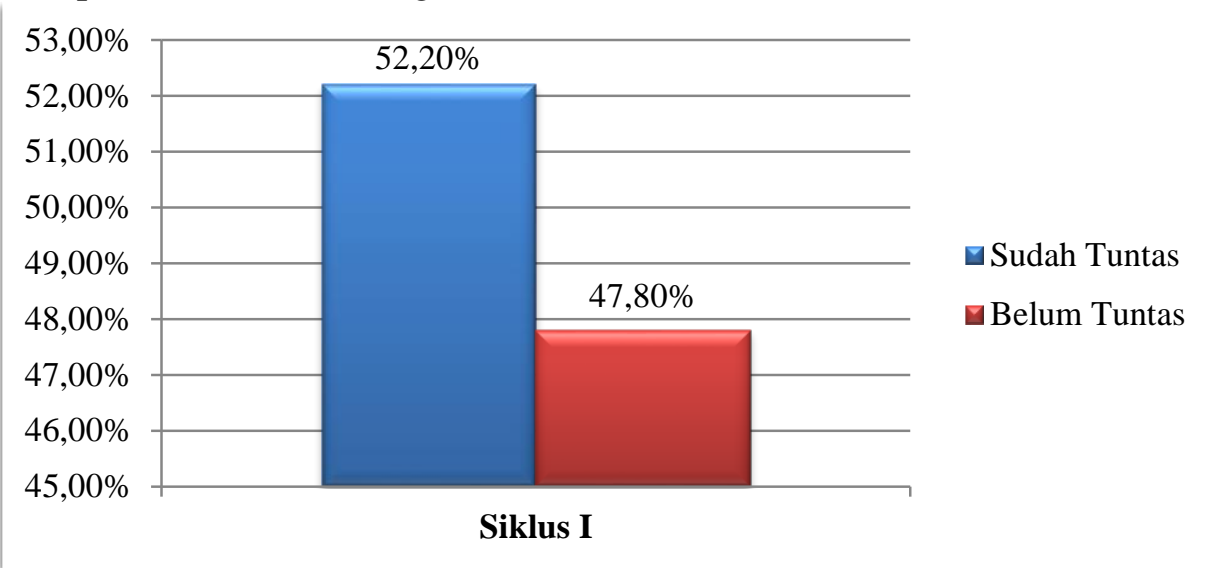

Gambar 3.6. Grafik Presentase Ketuntasan Siswa Siklus I

\section{Hasil Analisis Data Siklus II}

\section{Data Aktivitas Belajar Siswa Siklus II}

Data skor aktivitas belajar siswa dalam kegiatan belajar mengajar pada siklus II dapat dilihat pada tabel 4 berikut:

Tabel 3.4 Skor Rata-rata Aktivitas Belajar Siswa Siklus II

\begin{tabular}{|c|c|c|c|c|}
\hline \multirow{2}{*}{ No } & \multirow{2}{*}{ Indikator aktivitas siswa yang dinilai } & \multicolumn{3}{|c|}{ Skor/Siklus II } \\
\hline & & Pert 1 & Pert 2 & Rata-rata \\
\hline & Kegiatan Awal & & & \\
\hline 1 & $\begin{array}{l}\text { Siswa menyimak dengan fokus saat } \\
\text { pemeriksaan kehadiran dan menyiapkan } \\
\text { diri untuk belajar }\end{array}$ & 4 & 4 & 4 \\
\hline 2 & $\begin{array}{l}\text { Siswa memperhatikan berbagai alat bantu } \\
\text { dan sumber belajar yang berkaitan dengan } \\
\text { materi yang akan dipelajari }\end{array}$ & 3 & 4 & 3,5 \\
\hline 3 & $\begin{array}{l}\begin{array}{l}\text { Siswa mengingat kembali materi } \\
\text { sebelumnya }\end{array} \\
\end{array}$ & 4 & 4 & 4 \\
\hline 4 & Siswa termotivasi untuk belajar & 3 & 3 & 3 \\
\hline 5 & $\begin{array}{l}\text { Siswa mendengarkan dengan seksama apa } \\
\text { yang disampaikan }\end{array}$ & 3 & 3 & 3 \\
\hline 6 & $\begin{array}{lll}\begin{array}{l}\text { Siswa menyimak penjelasan yang } \\
\text { diterapkan }\end{array} & \\
\end{array}$ & 3 & 4 & 3,5 \\
\hline
\end{tabular}




\section{Kegiatan Inti}

\begin{tabular}{|c|c|c|c|c|}
\hline 7 & $\begin{array}{l}\text { Siswa mengemukakan pemahaman } \\
\text { awalnya terhadap materi, pemahaman awal } \\
\text { tersebut,dijadikan acuan r untuk } \\
\text { menyelidikinya (kontruktivisme) }\end{array}$ & 3 & 3 & 3 \\
\hline 8 & $\begin{array}{l}\text { Siswa bekerja sama dalam kelompok- } \\
\text { kelompok kecil (learning community) }\end{array}$ & 2 & 3 & 2,5 \\
\hline 9 & $\begin{array}{l}\text { Setiap kelompok siswa mendiskusikan } \\
\text { LKS menemukan alternative pemecahan } \\
\text { masalah terhadap masalah, dan apa yang } \\
\text { akan dilakukan setelah keputusan itu telah } \\
\text { tercapai, dengan menghubungkan persoalan } \\
\text { tersebut dengan konteks dilingkungan } \\
\text { siswa sendiri (inkuiry) }\end{array}$ & 3 & 3 & 3 \\
\hline 10 & $\begin{array}{l}\text { Siswa mengemukakan gambaran dan } \\
\text { contoh cara mengerjakan LKS }\end{array}$ & 3 & 3 & 3 \\
\hline 11 & $\begin{array}{l}\text { Siswa dalam kelompok saling } \\
\text { untuk bertanya } \\
\text { memecahkan } \\
\text { diberikankepada mereka dalam diskusi } \\
\text { kelompok }\end{array}$ & 2 & 3 & 2,5 \\
\hline 12 & $\begin{array}{l}\text { Siswa mencatat hasil diskusi kelompok } \\
\text { mereka, serta mengingat kembali kejadian- } \\
\text { kejadian yang dianggap kurang penting } \\
\text { yang dapat mengganggu jalanya proses } \\
\text { diskusi dalam kelompok }\end{array}$ & 3 & 3 & 3 \\
\hline 13 & $\begin{array}{l}\text { Siswa mempresentasikan hasil diskusi } \\
\text { kelompok mereka }\end{array}$ & 2 & 4 & 3 \\
\hline 14 & Siswa menanggapi pekerjaan temanya & 3 & 3 & 3 \\
\hline 15 & $\begin{array}{l}\text { Mengumpulkan hasil diskusi kelompoknya } \\
\text { kepada guru dan siswa menanyakan materi } \\
\text { yang kurang dimengerti }\end{array}$ & 4 & 4 & 4 \\
\hline & c.kegiatan Akhir & & & \\
\hline
\end{tabular}




\begin{tabular}{clccc}
16 & $\begin{array}{l}\text { Siswa menyimpulkan materi pelajaran yang } \\
\text { telah dipelajari }\end{array}$ & 3 & 3 & 3 \\
\hline 17 & Siswa mencatat tugas rumah & 3 & 4 & 3,5 \\
\hline $\begin{array}{l}\text { Rata-rata aktivitas siswa untuk semua } \\
\text { aspek }\end{array}$ & $\mathbf{3}$ & $\mathbf{3 , 4}$ & $\mathbf{3 , 2}$ \\
\hline Kategori & & & Baik
\end{tabular}

Sumber: Data Diolah (2017)

Gambaran rata-rata aktivitas

belajar siswa dapat dilihat pada Gambar

3.7 berikut:

\begin{tabular}{|c|c|c|c|c|}
\hline \multirow{2}{*}{ No } & \multirow{2}{*}{ Indikator aktivitas guru yang dinilai } & \multicolumn{3}{|c|}{ Skor/Siklus 1I } \\
\hline & & Pert 1 & Pert 2 & Rata-rata \\
\hline & Kegiatan Awal & & & \\
\hline 1 & $\begin{array}{l}\text { Guru memeriksa kehadiran siswa termasuk } \\
\text { mempersiapkan siswa belajar }\end{array}$ & 3 & 4 & 3,5 \\
\hline 2 & $\begin{array}{l}\text { Guru mempersiapkan berbagai alat bantu } \\
\text { dan sumber belajar }\end{array}$ & 3 & 3 & 3 \\
\hline 3 & $\begin{array}{l}\text { Guru melakukan apersepsi tentang materi } \\
\text { yang akan di pelajari }\end{array}$ & 3 & 4 & 3,5 \\
\hline 4 & Memotivasi siswa untuk mengikuti pelajaran & 2 & 3 & 2,5 \\
\hline 5 & Menyampaikan tujuan pembelajaran & 3 & 4 & 3,5 \\
\hline \multirow[t]{2}{*}{6} & $\begin{array}{l}\text { Mengemukakan langkah-langkah apa yang } \\
\text { akan dilakukan selama proses pembelajaran } \\
\text { berlangsung }\end{array}$ & 3 & 3 & 3 \\
\hline & Kegiatan Inti & & & \\
\hline 7 & $\begin{array}{l}\text { Guru mengemukakan informasi mengenai } \\
\text { materi }\end{array}$ & 3 & 4 & 3,5 \\
\hline 8 & $\begin{array}{lr}\text { Guru mendorong siswa mengemukakan } \\
\text { pemahaman awalnya } & \text { terhadap } \\
\text { materi,pemahaman awal tersebut dijadikan } \\
\text { acuan untuk } \\
\text { (kontruktivisme) }\end{array}$ & 3 & 3 & 3 \\
\hline
\end{tabular}


Guru membentuk, dan membimbing siswa

9 bekerja sama dalam kelompok-kelompok kecil (learning community)

$3 \quad 4 \quad 3,5$

Guru memberikan persoalan kepada setiap kelompok siswa,tetapi masih pada materi pelajaran yang sama,dimana setiap kelompok diajak berlatih mendiskusikan

10 LKS,menemukan alternative pemecahan terhadap masalah,dan apa yang akan 333 dilakukan setelah keputusan itu telah tercapai, dengan menghubungkan persoalan tersebut dengan konteks di lingkungan siswa sendiri (inkuiry)

Guru meberikan gambaran gambaran dan 11 contoh cara mengatasi suatu persoalan dalam suato organisasi (pemodelan)

$\begin{array}{lll}3 & 3 & 3\end{array}$

mendorong,membimbing,dan menilai kemampuan siswa bekerja secara kelompok dengan mengajukan pertanyaan-pertanyaan yang mengacu perkembangan pemahaman 12 mereka terhadap persoalan-persoalan yang diberikan kepada mereka, dengan menghubungkan antara materi dengan konteks keseharian siswa dilingkunganya (questioning)

\begin{tabular}{lllll}
\hline 13 & $\begin{array}{l}\text { guru membimbing siswa mencatat hasil } \\
\text { diskusi kelompok mereka }\end{array}$ & 4 & 4 & 4 \\
\hline 14 & guru membimbing jalanya diskusi & 3 & 4 & 3,5 \\
\hline 15 & $\begin{array}{l}\text { mengumpulkan hasil diskusi kelompok } \\
\text { siswa }\end{array}$ & 3 & 4 & 3,5 \\
\hline
\end{tabular}

\section{Kegiatan Akhir}


Guru memberikan kesimpuln terhadap materi yang telah dipelajari

2

3

2,5

Guru membimbing siswa untuk mengingat

kembali kejadian-kejadian yang dianggap

17 penting dan kurang penting yang dapat mengganggu proses diskusi dalam kelompok 4

4

4 (reflection)

\begin{tabular}{llccc}
\hline 18 & Guru memberi tugas kepada siswa & 3 & 3 & 3 \\
\hline Rata-rata aktivitas guru & $\mathbf{2 , 9}$ & $\mathbf{3 , 5}$ & $\mathbf{3 , 2}$ \\
\hline Kategori & & & Baik \\
\hline
\end{tabular}

\section{SIKLUS II}

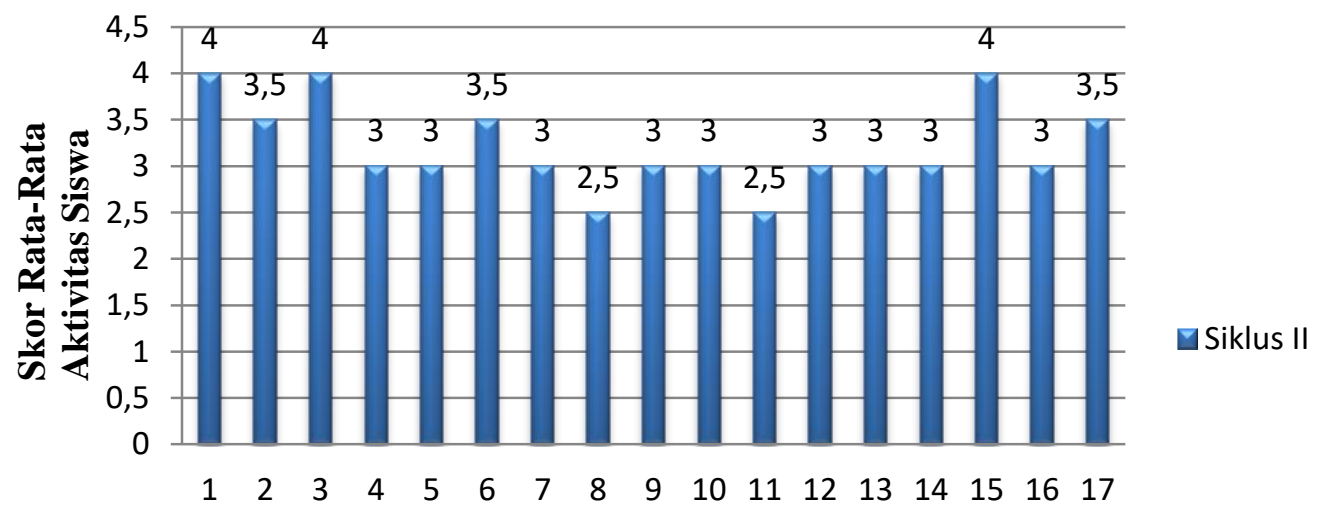

\section{Aktivitas Belajar Siswa}

\section{Gambar 3.7 Grafik Skor Rata-rata Satuan Aktivitas Belajar Siswa Siklus II}

Untuk mendapatkan gambaran rata-rata aktivitas belajar siswa selama pembelajaran pada siklus II pada pertemuan I dan II dapat dilihat pada Gambar 3.8 berikut: 


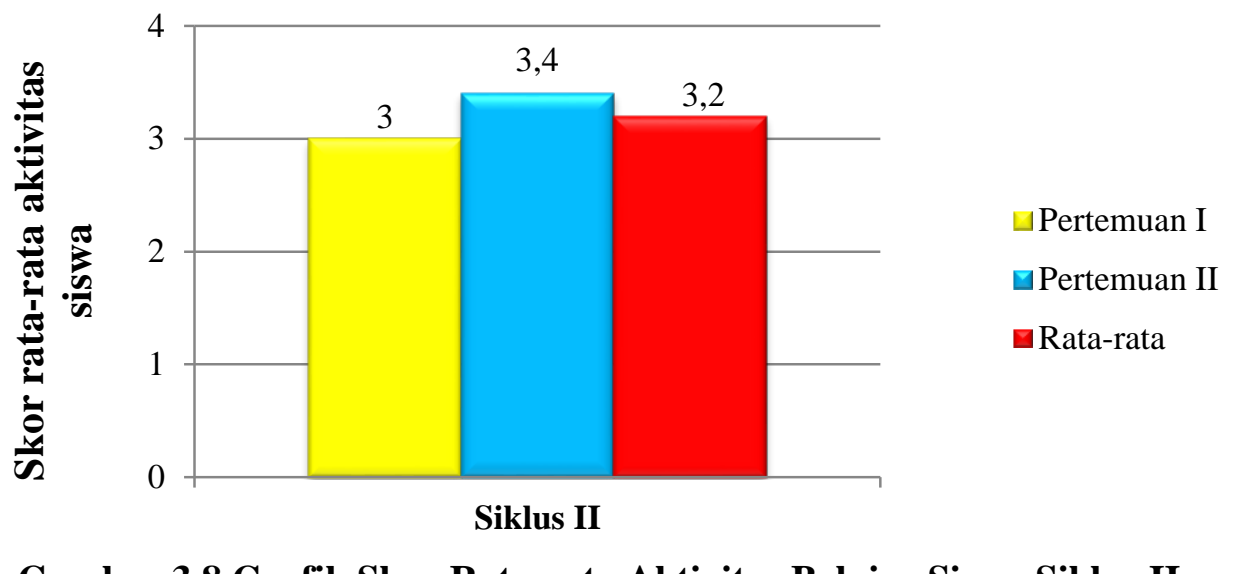

Gambar 3.8 Grafik Skor Rata-rata Aktivitas Belajar Siswa Siklus II

Data Aktivitas Guru Siklus II

Gambaran aktivitas guru Siklus II dapat dilihat pada tabel 3.5 berikut Gambaran rata-rata aktivitas guru dapat dilihat pada Gambar 3.9 berikut:

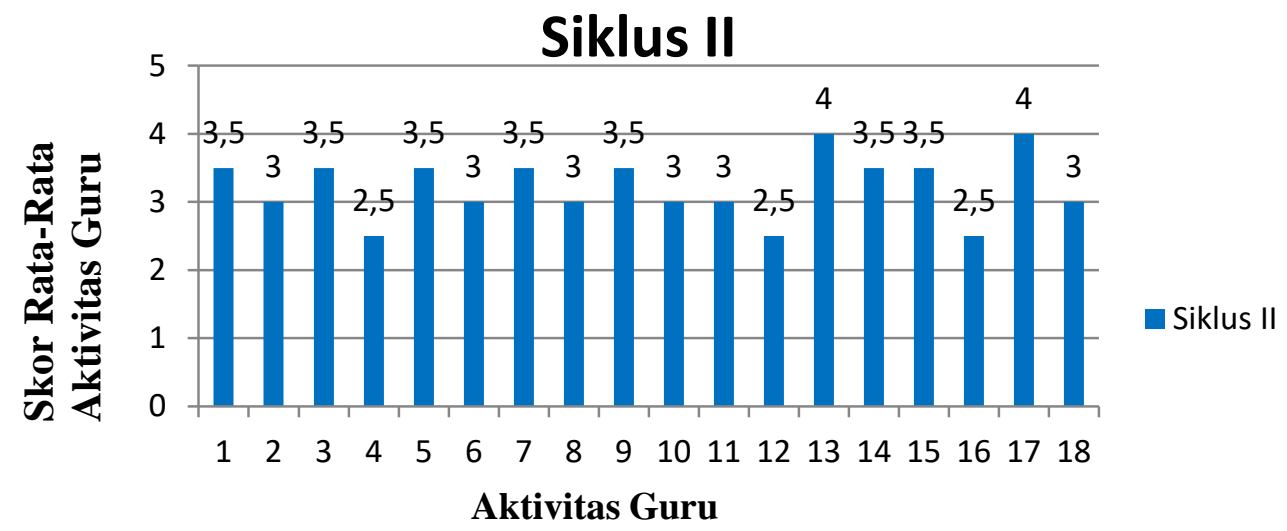

\section{Gambar 3.9 Grafik Skor Rata-rata Aktivitas Guru Siklus II}

Untuk mendapatkan gambaran rata-rata aktivitas guru selama pembelajaran pada siklus II dapat dilihat pada Gambar 3.10 berikut: 


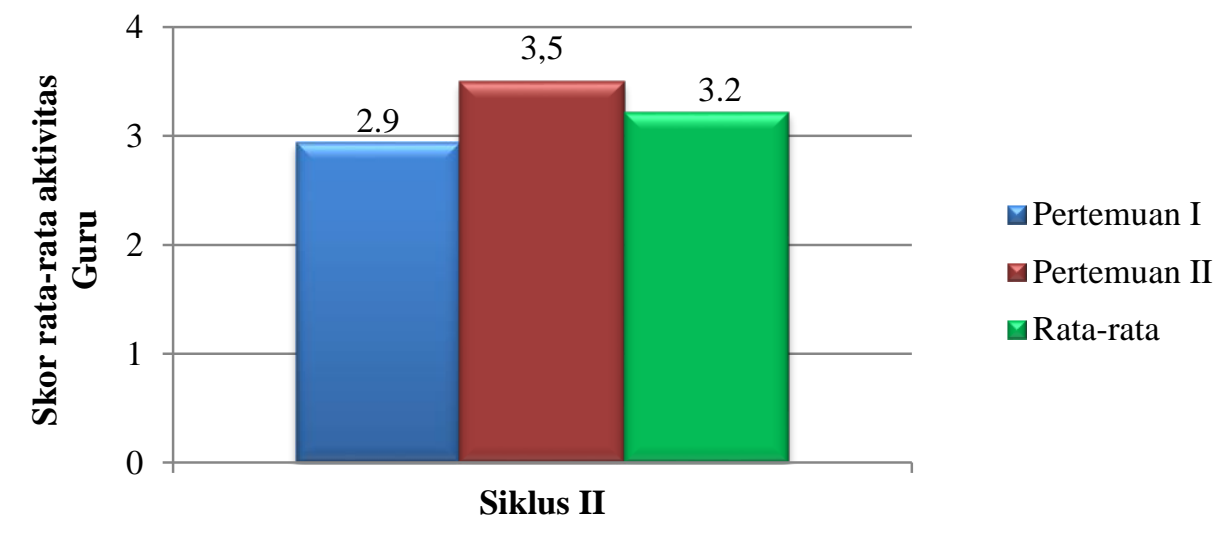

Gambar 3.10 Grafik Skor Rata-rata Aktivitas Guru Siklus II

\section{Data Hasil Belajar Siswa Siklus II}

Berdasarkan hasil analisis data hasil belajar siswa pada siklus II diperoleh hasil

sebagaimana disajikan pada table 3.6 berikut:

Tabel 3.6 Data Analisis Ketuntasan Hasil Belajar Siswa Siklus II

\begin{tabular}{lccc}
\hline Skor & Jumlah siswa & Presentase & Ketuntasan Belajar \\
\hline $0-69$ & 4 orang & $17 \%$ & Belum Tuntas \\
\hline $70-100$ & 19 orang & $83 \%$ & Sudah Tuntas \\
\hline Jumlah & $\mathbf{2 3}$ orang & $\mathbf{1 0 0 \%}$ & \\
\hline Keterangan & $:$ & & \\
\hline Tidak Tuntas & $\mathbf{4}$ orang \\
\hline Tuntas & $: \mathbf{1 9}$ orang \\
\hline Nilai Rata-rata & $\mathbf{0 7 8 , 1 7}$ & \\
\hline Nilai Maksimum & $\mathbf{: 9 5}$ \\
\hline Nilai Minimum & $\mathbf{5 3 , 3}$ \\
\hline Presentase Ketuntasan & $\mathbf{8 3 \%}$ \\
\hline
\end{tabular}

Sumber: Data Diolah (2017)

Untuk gambaran hasil belajar siswa pada siklus II dapat dilihat pada gambar 3.11 berikut: 


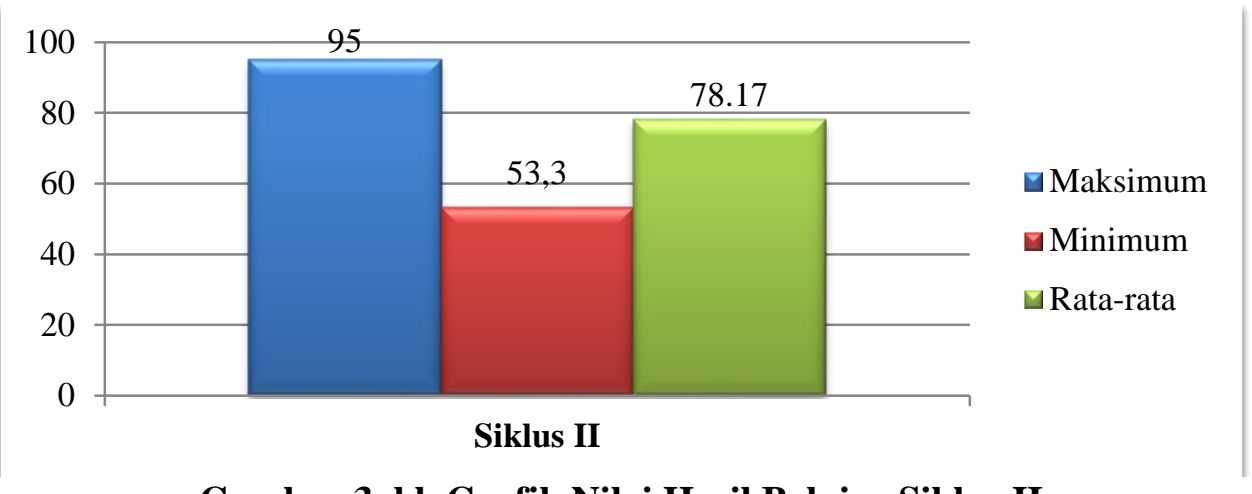

Gambar 3. 1 Grafik Nilai Hasil Belajar Siklus II

Selanjutnya berdasarkan analisis diperoleh hasil sebagaimana disajikan ketuntasan belajar siswa pada siklus II pada gambar 3.12 berikut:

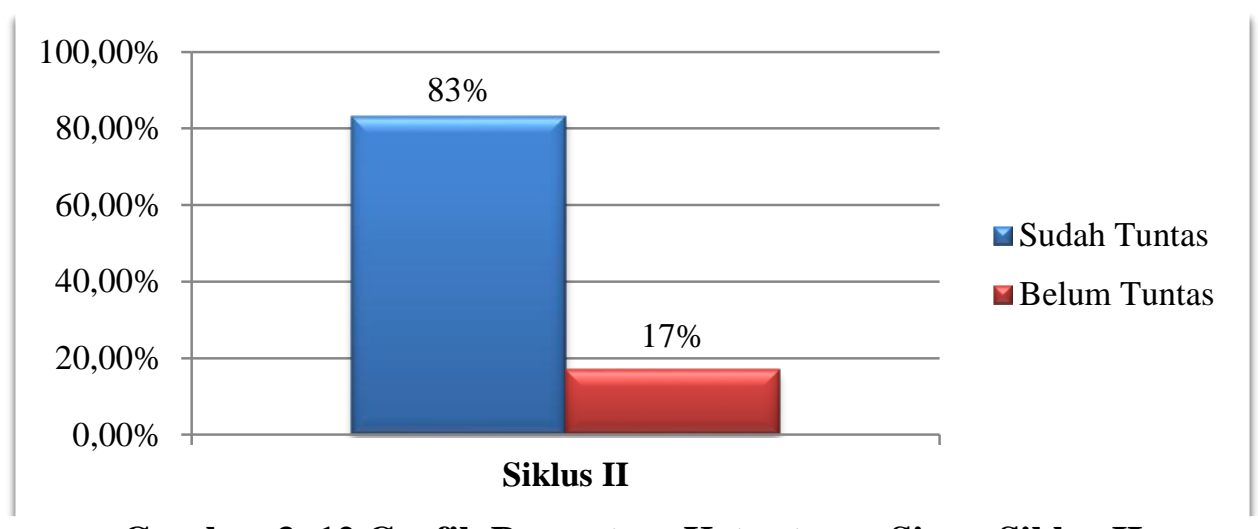

Gambar 3. 12 Grafik Presentase Ketuntasan Siswa Siklus II

\section{PEMBAHASAN}

\section{Aktivitas Belajar Siswa selama KBM Berlangsung}

Pada siklus II dari hasil analisis deskriptif terhadap skor rata-rata aktivitas belajar siswa pada siklus II menunjukkan adanya peningkatan yang signifikan dari aktivitas belajar siswa siklus I. dimana skor rata-rata aktivitas belajar siswa pada siklus II sebesar 3,2 dengan kategori Baik. Hal ini menunujukan bahwa penelitian telah berhasil karena telah memenuhi standar minimal aktivitas siswa yaitu 3,0.

\section{Aktivitas mengajar Guru}

Hasil analisis dan pengamatan pada siklus II ini menunjukkan adanya peningkatan aktivitas guru dengan menerapkan Pendekatan Pembelajaran Contextual Teaching And Learning. Hal ini menunujukan bahwa penelitian telah berhasil karena telah memenuhi standar minimal aktivitas mengajar guru yaitu 3,0. 
Masnur Muslich. (2007). KTSP pembelajaran berbasis kompetensi dan kontekstual panduan bagi guru, kepala sekolah, dan pengawas sekolah, Jakarta: Bumi Aksara

Mulyasa. 2006. Menjadi Guru professional, Bandung: Pustaka Setia.

Musfiqun. 2012. Pengembangan Media dan Sumber Pembelajaran. Jakarta: PT Prestasi Pustakaraya.

Nurhadi, dkk. 2003. Pembelajaran Kontekstual dan penerapannya dalam KBK. Malang: universitas Negeri Malang.

Rusman. 2012. Belajar dan pembelajaran berbasis komputer. Bandung : Alfabeta, CV.

Sudjana. 2010. Penilaian proses dan hasil belajar mengajar . Bandung: Sinar Baru Algensindo Offset.

Sukaria. 2012. meningkatkan hasil belajar pendidikan kewargenagaraan pada materi mengemukaan pendapat melalui penerapan model pembelajaran Contextual Teaching Learning di kelas VII-c SMP Negeri 1 Lasalimu S elatan. Kendari: Universitas Halu Oleo Kendari.

Sumaatmadja, Nursid. 2001. Metodologi Pengajaran Geografi. Jakarta: PT Bumi Aksara.

Suparno, P. 2008. Riset Tindakan untuk Pendidik. Jakarta : PT.Gramedia Widiasarana.
Susetyo, 2008. Statistika Untuk Analilsis Data Penelitian. Bandung: Refika Ditama.

Syaiful, 2002. Strategi Belajar Mengajar, Jakarta: Rineka Cipta.

Trianto. 2009. Model-model Pembelajaran Inovatif Berorientasi Kontruktivistik. Jakarta: Prestasi Pustaka Raya.

Usman dan Setiawati, 2001. Upaya optimalisasi kegiatan belajar mengajar. Bandung: Remaja Rosdakarya. 